\title{
PROFIT PER EMPLOYEE ANALYSIS (BASED ON FOUR MAJOR ESTONIAN SUPERMARKET CHAINS IN 2010-2014)
}

\author{
Mark Gofaizen \\ Department of Accounting, Tallinn University of Technology, Estonia \\ Paavo Siimann \\ Department of Accounting, Tallinn University of Technology, Estonia \\ Jaan Alver \\ Department of Accounting, Tallinn University of Technology, Estonia
}

\begin{abstract}
The supermarket industry in Estonia plays a significant role in growth of gross domestic product (GDP), as it constituted approximately 43\% of total retail trade in 2015 and growth amounted to $36 \%$ during the period of 2010-2015. At the same time, the growth of shopping gross leasable area (GLA) in Estonia plays a significant role in supermarket saturation, because an increase in GLA leads to strong competition and disperses demand between all the retail players. The veracity of this research is supported by a sharp increase in the number of retail stores by different companies and supermarket chains. The purpose of this study is to analyse the formation of profit per employee of four major Estonian supermarket chains during the period 2010-2014 by using publicly available annual reports.

Two methods - efficiency matrix analysis and ranking of supermarket chains based on overall performance efficiency indicator (OPEI) - were selected by the authors. Primarily, such methodology was chosen due to its multidimensional specifics and the fact that it can provide a systematic and comprehensive picture of a company's financial position and all financial ratios to be analysed in a clearly expressed relationship.

In general, it was found that profit per employee fell in regard to both Maxima and Selver during the 2010-2014 period. In the case of Rimi, it was volatile and increased in 2013, but it decreased in 2014. Only in the case of Prisma did this component show positive growth during the 2010 2014 period. According to component analysis, profit margin mainly impacted changes in profit per employee for all the companies investigated.

According to the OPEI, Selver had the highest performance efficiency overall, aside from 2014 when Prisma was the most efficient as it had the highest increase in profit per employee in 2014.
\end{abstract}

Keywords: financial statement analysis, matrix analysis, performance index, supermarkets

JEL code: M21, M41

\section{Introduction}

Nowadays, shopping centres make life easier and are very important for economic growth, because domestic consumption plays an important role in gross domestic product (GDP) increase. There has been a significant increase in the net sales of the four major Estonian supermarket chains. According to the annual reports of the main supermarket chains in Estonia (for 2009-2014), total sales grew by 33.5\%. Also, it should be noted that shopping gross leasable area (GLA) plays a significant role in the retail sector, because the demand of the population is dispersed among all retailers if there is an increase of leasable area for retail trade. Accordingly, sales and profits in the same sector of individual stores and store chains decreases.

According to the "Cushman \& Wakefield" report in 2014, the average gross shopping leasable area (GLA) in European Union was 250 square metres per 1,000 people. Some examples of 
GLA for developed economies in the European Union include Germany with 180, France with 370 and Sweden with 410 square metres per 1,000 people. At the same time, there were 460 square metres of retail space available in Estonia per 1,000 people (Cushman \& Wakefield Research Publication, 2014, P. 18).

Based on 2013 data collected by DTZ, a privately owned commercial real estate firm, it can be seen from Figure 1 that total shopping centre floor-space per capita was 1,066 in Tallinn in 2011, while in Paris that value was equal to 192, in Berlin 402 and in Stockholm 869 (DTZ. European Retail Guide, 2013).

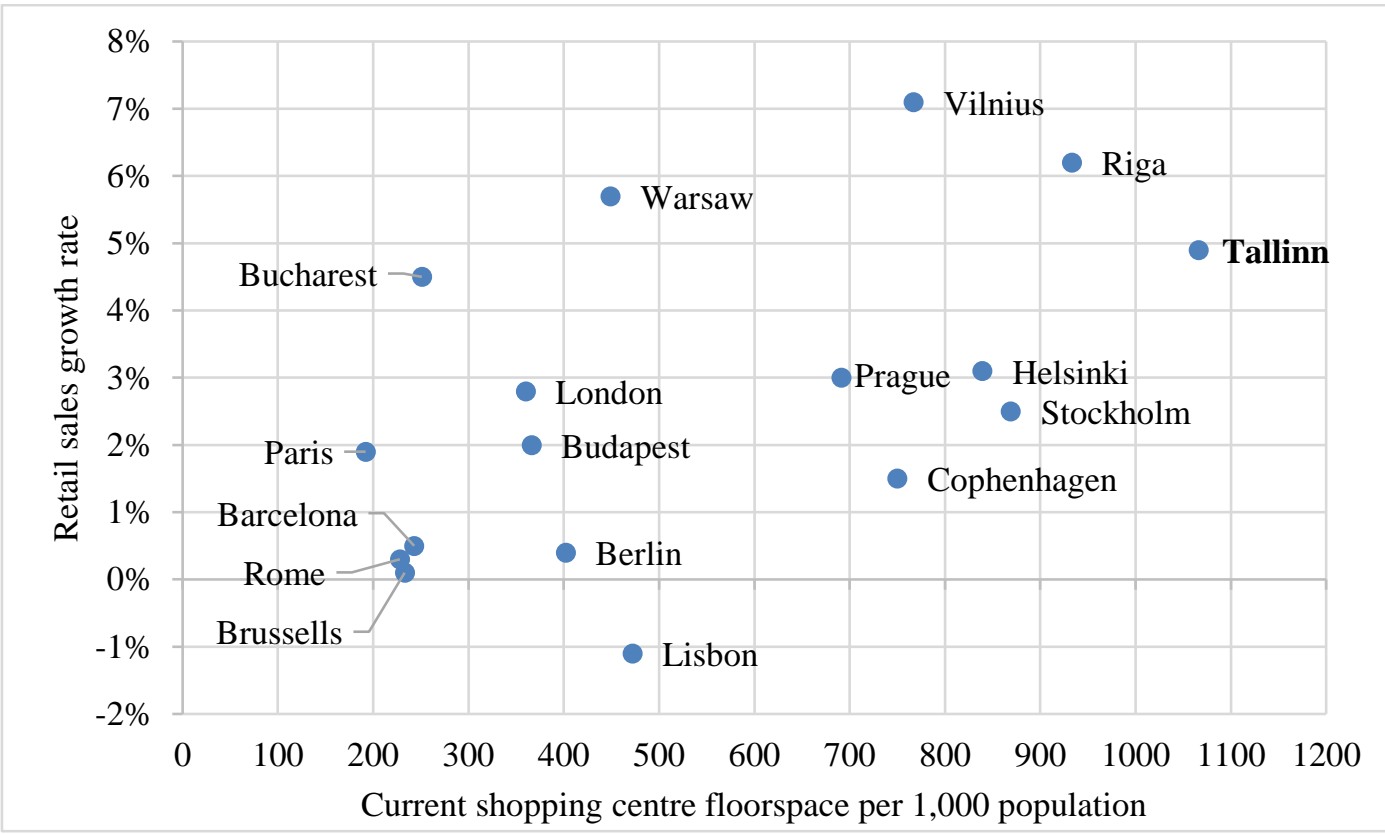

Figure 1. Shopping centre floor space per 1,000 people in 2013 and forecast retail sales growth (2012-2016) in major European cities

Source: compiled by the authors (DTZ, 2013,9)

It is important to note that the 2015 minimum monthly wage in Luxemburg was 1,900 EUR and in Norway was 2,650 EUR, while in Estonia it was only 390 EUR (European Commission, 2015). Comparatively, nowadays Estonia is one of the leaders in the number of retail spaces per capita in Europe, but purchasing power in Estonia is 35\% below the EU average (Eurostat, 2015). Therefore, on the basis of an objective economic law that demand determines supply, it is possible to hypothesise that the trend of growth in sales and profits of major Estonian retailers could soon start to decline.

The veracity of this research is supported by the constant growth of retail trade in Estonia, with a sharp increase in the number of retail stores by different companies and supermarket chains. According to Statistics Estonia, it can be seen that retail sales, aside from motor vehicles and motorcycles, grew by $46.8 \%$ and amounted to 5,187.6 million euros in 2015 in comparison to 2010, when it was 3,531.9 million euros. (Statistics Estonia, 2016) Increasing competition between commercial enterprises requires the optimisation of business processes to improve efficiency, maximise profits and reduce costs. The purpose of this study is to analyse the formation of profit per employee in the Estonian supermarket industry during the period of 2010-2014 by using publicly available annual reports. The focus of this study is the four biggest supermarket chains on the Estonian market (Maxima, Selver, Prisma and Rimi). There will be two research questions investigated in this article: 
1. Which qualitative indicators influenced the most changes in profit per employee during 2010-2014?

2. Which supermarket chain was the most efficient in earning profit per employee in 2010 2014 ?

The research has been conducted based on audited annual reports available in the Estonian Commercial Register.

This article makes an empirical contribution to spreading the use of the efficiency matrix and its developments.

\section{Study methods}

The authors selected two methods: efficiency matrix analysis and the ranking of supermarket chains based on overall performance efficiency indicator (OPEI). Primarily, such methodology was chosen due to its multidimensional specifics. For example, Siimann and Alver (2015) in their article "On using an efficiency matrix in analysing profit per employee" specified that matrix modeling could be used in different sectors and on many different levels. At the same time, they mentioned that the matrix model in comparison to other indicator systems gives a more systematic and comprehensive picture of a company's financial position and all financial ratios that are to be analysed in a clearly expressed relationship.

The idea of using an efficiency matrix when investigating the economic efficiency of companies was initially introduced by Estonian academician Uno Mereste in 1965. The initial methodology developed by Mereste has been developed further by Luur (1982), Root (1983), Mereste (1984, 1987), Alver and Järve (1989), Volt (1989), Sarap (1989) and Vensel (2001). The selection and sequence of quantitative indicators plays an important role when compiling an efficiency matrix. Alver and Järve (1987) proposed a sequence of indicators in a way that a company's resources are converted through expenses into results.

Consequently, the authors of this research paper selected five indicators to include them in the efficiency matrix for the analysis of each selected supermarket chain (see table 1). Allowing for the specifics of the retail sector, the following indicators were included in the efficiency matrix.

The resource indicators include:

- Number of employees (E);

- Machinery and equipment (M).

Expense indicator:

- Goods, materials and services (COGS, C).

Result indicators:

- Net sales (S);

- Operating profit $(\mathrm{P})$.

These resources indicators were selected that initially company hires employees and then purchases equipment and machinery for further activities. Equipment and machinery are reflected in initial cost (not depreciated) in the matrix model to eliminate differences in useful lives among supermarkets chains. COGS was selected as an expense indicator due to it having the highest proportion to sales, which varied depending on the supermarket chain from $76.2 \%$ 
to $89.6 \%$ during period of $2010-2014$. Operating profit instead of net profit was chosen to eliminate differences driven by the financing strategy and dividend policy of companies ${ }^{1}$.

Table 1. The matrix model

\begin{tabular}{|c|c|c|c|c|c|}
\hline $\begin{array}{l}\text { Quant- } \\
\text { itative } \\
\text { indicator }\end{array}$ & $\begin{array}{l}\text { Operating } \\
\text { profit }(\mathrm{P})\end{array}$ & Net sales (S) & COGS (C) & $\begin{array}{l}\text { Machinery } \\
\text { (M) }\end{array}$ & $\begin{array}{c}\text { Number of } \\
\text { employees } \\
\text { (E) }\end{array}$ \\
\hline $\mathrm{P}$ & 1.0 & & & & \\
\hline$S$ & $\begin{array}{l}12 \quad \text { P/S } \\
\text { Profit } \\
\text { Margin }\end{array}$ & $\begin{array}{r}22 \\
1.0\end{array}$ & & & \\
\hline C & $\begin{array}{l}13 \quad \mathrm{P} / \mathrm{C} \\
\text { Profit to } \\
\text { COGS }\end{array}$ & $\begin{array}{c}23 \quad \mathrm{~S} / \mathrm{C} \\
\text { Net sales to } \\
\text { COGS }\end{array}$ & $\begin{array}{r}33 \\
1.0\end{array}$ & & \\
\hline $\mathrm{M}$ & $\begin{array}{l}14 \quad \mathrm{P} / \mathrm{M} \\
\text { Profit to } \\
\text { Machinery }\end{array}$ & $\begin{array}{c}24 \quad \mathrm{~S} / \mathrm{M} \\
\text { Net sales to } \\
\text { Machinery }\end{array}$ & $\begin{array}{c}34 \quad \mathrm{C} / \mathrm{M} \\
\text { COGS to } \\
\text { Machinery }\end{array}$ & $\begin{array}{r}44 \\
1.0\end{array}$ & \\
\hline E & $\begin{array}{c}15 \quad \mathrm{P} / \mathrm{E} \\
\text { Profit per } \\
\text { Employee }\end{array}$ & $\begin{array}{c}25 \mathrm{~S} / \mathrm{E} \\
\text { Net sales per } \\
\text { Employee }\end{array}$ & $\begin{array}{l}35 \quad \mathrm{C} / \mathrm{E} \\
\text { COGS per } \\
\text { employee }\end{array}$ & $\begin{array}{c}45 \quad \mathrm{M} / \mathrm{E} \\
\text { Machinery } \\
\text { per } \\
\text { employee }\end{array}$ & 1.0 \\
\hline
\end{tabular}

Source: compiled by the authors

Profit per employee (cell 15) is the principle ratio investigated. It can be concluded from the efficiency matrix (Table 1) that profit per employee is the multiplication of ratios located below the main diagonal (cells 12, 23, 34 and 45; see Formula 1).

$$
\frac{P}{E}=\frac{M}{E} \times \frac{C}{M} \times \frac{S}{C} \times \frac{P}{S}
$$

where $\frac{P}{E}$ - profit per employee;

$\frac{M}{E}$ - machinery and equipment per employee;

$\frac{C}{M}-$ COGS to Machinery;

$\frac{S}{C}-$ net sales to COGS;

$\frac{P}{S}$ - profit margin.

To measure the impact of each component to change in profit per employee, component analysis was conducted using the ratios under main diagonal ${ }^{2}$.

The second method of the study was to rank the supermarket chains based on OPEI. According to research conducted by Uno Mereste $(1984,156)$, the ranking of enterprises by OPEI can be conducted by using arithmetic means from the all indices of efficiency matrix under the main diagonal (Formula 2).

$$
O P E I=\frac{2 \times \sum I}{n^{2}-n}
$$

\footnotetext{
${ }^{1}$ In Estonia corporate income tax has to be paid only when dividends are distributed. Corporate income tax does not apply to earned profit.

${ }^{2}$ See Siimann and Alver (2015, p 203-205) for further details.
} 
where

$I$ - indices of efficiency matrix;

$n$ - number of initial quantitative indicators.

At the same time, in his $\mathrm{PhD}$ thesis Root (1983) provided the ranking of enterprises by OPEI by using geometric mean from the indices of efficiency matrix variable composition (Formula $3)$ :

$$
I_{E}=\sqrt[\frac{n^{2}-n}{2}]{\Pi I}
$$

According to Alver (2015, p. 12), "OPEI can be used to compare enterprises based on the relative economic efficiency of their business activities. At the same time, OPEI can be used by ranking enterprises based on relative changes (dynamics) in the economic efficiency of their business activities".

\section{Results and discussion}

\section{Matrix Analysis}

There were diverse developments in profit per employee (P/E) among supermarkets investigated during the period 2010-2014. According to calculations provided in tables 2 and 3 , Selver had the highest profit per employee (3.33-7.74 thousand euros per employee) in 2010 2013 and Prisma in 2014 (6.56 thousand euros per employee). In 2011, three out of four supermarkets (Maxima, Rimi and Prisma) had negative profit per employee. For Maxima and Selver, profit per employee declined (from 2.60 to 0.93 and 5.97 to 3.43 thousand euros per employee and CAGR -23\% and -13\%. respectively) during 2010-2014. In Rimi's case, it was volatile and increased from -1.63 in 2010 to 1.45 thousand euros per employee in 2013, but in 2014 it decreased down to $€ 0.03$ th/employee. Only Prisma's profit per employee grew (to be exact, loss declined from -.67 to -6.56 thousand euros per employee) during 2010-2014.

For Maxima, the biggest decrease in profit per employee (P/E) occurred in 2011, when operating profit per employee declined from 2.6 thousand euros per employee in 2010 to -2.53 thousand euros per employee in 2011. As can be concluded from the matrix (Table 2), such a rapid decrease was caused by the $\mathrm{P} / \mathrm{S}$ factor ( $96 \%$ impact to total change). A decrease in profit margin (P/S) from $2.6 \%$ to $-2.8 \%$ was due to the impairment of tangible assets when Maxima sold 26 objects and other operating expenses increased. In 2012-2014, Maxima's profit per employee fluctuated between 0.93 and 1.02 thousand euros per employee. In 2013, a slight increase (from 0.93 to 1.02 th/employee) was driven by investments in machinery, which caused an increase in the M/E component. However, a decline in profit per employee in 2014 was again mainly influenced by a decrease in profit margin.

In Selver's case, the majority of changes in profit per employee can be explained by changes in profit margin. Selver had a major change in profit per employee in 2013, when profit per employee decreased from 6.38 to 3.33 thousand euros per employee (Table 2). Such a decline was mainly caused by profit margin component as due to decrease of profit margin from $4 \%$ to $2 \%$, profit per employee declined by 3.47 thousand euros per employee. This was mainly driven by share of materials and consumables growth to total sales in income statement. 
Table 2. Aggregated indicators (th $€$ and full time employees). Components under the diagonal of the efficiency matrix and the absolute and relative impacts of each component on the change in profit per employee based on the aggregated indicators of the Maxima and Selver supermarket chains.

\begin{tabular}{|c|c|c|c|c|c|c|c|c|c|c|}
\hline \multirow[b]{2}{*}{ Year/Component } & \multicolumn{5}{|c|}{ MAXIMA } & \multicolumn{5}{|c|}{ SELVER } \\
\hline & $\mathrm{P}$ & $S$ & $\mathrm{C}$ & $\bar{M}$ & $\mathrm{E}$ & $\mathrm{P}$ & $S$ & $\mathrm{C}$ & $\mathrm{M}$ & $\mathrm{E}$ \\
\hline 2014 & 3420 & 400849 & 355445 & 32227 & 3696 & 7671 & 367486 & 291801 & 40316 & 2237 \\
\hline 2013 & 3615 & 380552 & 336810 & 28794 & 3534 & 6888 & 342748 & 271045 & 39797 & 2066 \\
\hline 2012 & 3322 & 336272 & 301265 & 22443 & 3575 & 13553 & 330549 & 254511 & 34298 & 2124 \\
\hline 2011 & -8014 & 291238 & 261446 & 18455 & 3164 & 16223 & 318703 & 242782 & 33336 & 2096 \\
\hline 2010 & 6675 & 257431 & 226449 & 17569 & 2563 & 11796 & 309656 & 236099 & 32245 & 1975 \\
\hline $2014 / 2013$ & 0.95 & 1.05 & 1.06 & 1.12 & 1.05 & 1.11 & 1.07 & 1.08 & 1.01 & 1.08 \\
\hline $2013 / 2012$ & 1.09 & 1.13 & 1.12 & 1.28 & 0.99 & 0.51 & 1.04 & 1.06 & 1.16 & 0.97 \\
\hline $2012 / 2011$ & -0.41 & 1.15 & 1.15 & 1.22 & 1.13 & 0.84 & 1.04 & 1.05 & 1.03 & 1.01 \\
\hline $2011 / 2010$ & -1.20 & 1.13 & 1.15 & 1.05 & 1.23 & 1.38 & 1.03 & 1.03 & 1.03 & 1.06 \\
\hline CAGR 2014/2010 & 0.85 & 1.12 & 1.12 & 1.16 & 1.10 & 0.90 & 1.04 & 1.05 & 1.06 & 1.03 \\
\hline CAGR 2013/2010 & 0.82 & 1.14 & 1.14 & 1.18 & 1.11 & 0.84 & 1.03 & 1.05 & 1.07 & 1.02 \\
\hline CAGR 2012/2010 & 0.71 & 1.14 & 1.15 & 1.13 & 1.18 & 1.07 & 1.03 & 1.04 & 1.03 & 1.04 \\
\hline GR 2011/2010 & -1.20 & 1.13 & 1.15 & 1.05 & 1.23 & 1.38 & 1.03 & 1.03 & 1.03 & 1.06 \\
\hline & $\mathrm{P} / \mathrm{E}$ & $\mathrm{P} / \mathrm{S}$ & $\mathrm{S} / \mathrm{C}$ & $\mathrm{C} / \mathrm{M}$ & $\mathrm{M} / \mathrm{E}$ & $\mathrm{P} / \mathrm{E}$ & $\mathrm{P} / \mathrm{S}$ & $\mathrm{S} / \mathrm{C}$ & $\mathrm{C} / \mathrm{M}$ & $\mathrm{M} / \mathrm{E}$ \\
\hline 2014 & 0.93 & $1 \%$ & 1.13 & 11.03 & 8.72 & 3.43 & $2 \%$ & 1.26 & 7.24 & 18.02 \\
\hline 2013 & 1.02 & $1 \%$ & 1.13 & 11.70 & 8.15 & 3.33 & $2 \%$ & 1.26 & 6.81 & 19.26 \\
\hline 2012 & 0.93 & $1 \%$ & 1.12 & 13.42 & 6.28 & 6.38 & $4 \%$ & 1.30 & 7.42 & 16.15 \\
\hline 2011 & -2.53 & $-3 \%$ & 1.11 & 14.17 & 5.83 & 7.74 & $5 \%$ & 1.31 & 7.28 & 15.90 \\
\hline 2010 & 2.60 & $3 \%$ & 1.14 & 12.89 & 6.85 & 5.97 & $4 \%$ & 1.31 & 7.32 & 16.33 \\
\hline $2014 / 2013$ & 0.90 & 0.90 & 1.00 & 0.94 & 1.07 & 1.03 & 1.04 & 1.00 & 1.06 & 0.94 \\
\hline $2013 / 2012$ & 1.10 & 0.96 & 1.01 & 0.87 & 1.30 & 0.52 & 0.49 & 0.97 & 0.92 & 1.19 \\
\hline $2012 / 2011$ & -0.37 & -0.36 & 1.00 & 0.95 & 1.08 & 0.82 & 0.81 & 0.99 & 1.02 & 1.02 \\
\hline $2011 / 2010$ & -0.97 & -1.06 & 0.98 & 1.10 & 0.85 & 1.30 & 1.34 & 1.00 & 0.99 & 0.97 \\
\hline CAGR 2014/2010 & 0.77 & 0.76 & 1.00 & 0.96 & 1.06 & 0.87 & 0.86 & 1.00 & 1.00 & 1.03 \\
\hline CAGR 2013/2010 & 0.73 & 0.72 & 1.00 & 0.97 & 1.06 & 0.82 & 0.81 & 0.98 & 0.98 & 1.06 \\
\hline CAGR 2012/2010 & 0.60 & 0.62 & 0.99 & 1.02 & 0.96 & 1.03 & 1.04 & 1.01 & 1.01 & 0.99 \\
\hline GR 2011/2010 & -0.97 & -1.06 & 0.99 & 1.10 & 0.85 & 1.30 & 1.34 & 0.99 & 0.99 & 0.97 \\
\hline \multirow[t]{2}{*}{$\Delta \mathrm{P} / \mathrm{E}$} & $\Delta \mathrm{P} / \mathrm{E}$ & $(\mathrm{P} / \mathrm{S})$ & $(\mathrm{S} / \mathrm{C})$ & $(\mathrm{C} / \mathrm{M})$ & $(\mathrm{M} / \mathrm{E})$ & $\Delta \mathrm{P} / \mathrm{E}$ & $(\mathrm{P} / \mathrm{S})$ & $(\mathrm{S} / \mathrm{C})$ & $(\mathrm{C} / \mathrm{M})$ & $(\mathrm{M} / \mathrm{E})$ \\
\hline & & 0.93 & 1.03 & 1.03 & 1.09 & & 3.43 & 3.30 & 3.31 & 3.11 \\
\hline \multirow[t]{2}{*}{$2014 / 2013$} & -0.10 & -0.10 & 0.00 & -0.06 & 0.07 & 0.10 & 0.13 & -0.01 & 0.20 & -0.21 \\
\hline & $100 \%$ & $108 \%$ & $2 \%$ & $64 \%$ & $-74 \%$ & $100 \%$ & $134 \%$ & $-14 \%$ & $206 \%$ & $-226 \%$ \\
\hline \multirow{3}{*}{$2013 / 2012$} & & 1.02 & 1.06 & 1.05 & 1.21 & & 3.33 & 6.80 & 6.99 & 7.61 \\
\hline & 0.09 & -0.04 & 0.01 & -0.16 & 0.28 & -3.05 & -3.47 & -0.18 & -0.63 & 1.23 \\
\hline & $100 \%$ & $-44 \%$ & $14 \%$ & $-166 \%$ & $295 \%$ & $100 \%$ & $114 \%$ & $6 \%$ & $21 \%$ & $-40 \%$ \\
\hline \multirow{3}{*}{$2012 / 2011$} & & 0.93 & -2.59 & -2.58 & -2.72 & & 6.38 & 7.92 & 8.01 & 7.86 \\
\hline & 3.46 & 3.52 & -0.01 & 0.14 & -0.19 & -1.36 & -1.54 & -0.09 & 0.15 & 0.12 \\
\hline & $100 \%$ & $102 \%$ & $0 \%$ & $4 \%$ & $-6 \%$ & $100 \%$ & $113 \%$ & $6 \%$ & $-11 \%$ & $-9 \%$ \\
\hline \multirow{3}{*}{$2011 / 2010$} & & -2.53 & 2.39 & 2.44 & 2.22 & & 7.74 & 5.79 & 5.78 & 5.81 \\
\hline & -5.14 & -4.92 & -0.05 & 0.22 & -0.39 & 1.77 & 1.95 & 0.01 & -0.03 & -0.15 \\
\hline & $100 \%$ & $96 \%$ & $1 \%$ & $-4 \%$ & $8 \%$ & $100 \%$ & $110 \%$ & $0 \%$ & $-2 \%$ & $-9 \%$ \\
\hline
\end{tabular}

Source: compiled by the authors, annual reports 2010-2014. 
Table 3. Aggregated indicators (thousands euros and full time employees). Components under the diagonal of the efficiency matrix and the absolute and relative impacts of each component on the change in profit per employee based on the aggregated indicators of the Rimi and Prisma supermarket chains.

\begin{tabular}{|c|c|c|c|c|c|c|c|c|c|c|}
\hline & \multicolumn{5}{|c|}{ RIMI } & \multicolumn{5}{|c|}{ PRISMA } \\
\hline Year/Component & $\mathrm{P}$ & $S$ & $\mathrm{C}$ & $M$ & $\mathrm{E}$ & $\mathrm{P}$ & $S$ & $\mathrm{C}$ & $M$ & $\mathrm{E}$ \\
\hline 2014 & 52 & 363118 & 306017 & 48740 & 2070 & 6665 & 207596 & 167668 & 27896 & 1016 \\
\hline 2013 & 2967 & 360941 & 301053 & 48707 & 2051 & 1746 & 194115 & 158384 & 27076 & 1062 \\
\hline 2012 & 2734 & 359115 & 301398 & 49345 & 2102 & 2666 & 177357 & 143675 & 27198 & 988 \\
\hline 2011 & -595 & 351591 & 300372 & 46902 & 2032 & -569 & 147415 & 119881 & 23955 & 906 \\
\hline 2010 & -3314 & 341683 & 293881 & 45452 & 2027 & -484 & 118473 & 95918 & 22126 & 724 \\
\hline $2014 / 2013$ & 0.02 & 1.01 & 1.02 & 1.00 & 1.01 & 3.82 & 1.07 & 1.06 & 1.03 & 0.96 \\
\hline $2013 / 2012$ & 1.09 & 1.01 & 1.00 & 0.99 & 0.98 & 0.65 & 1.09 & 1.10 & 1.00 & 1.07 \\
\hline $2012 / 2011$ & -4.59 & 1.02 & 1.00 & 1.05 & 1.03 & -4.69 & 1.20 & 1.20 & 1.14 & 1.09 \\
\hline $2011 / 2010$ & 0.18 & 1.03 & 1.02 & 1.03 & 1.00 & 1.18 & 1.24 & 1.25 & 1.08 & 1.25 \\
\hline CAGR 2014/2010 & - & 1.02 & 1.01 & 1.02 & 1.01 & - & 1.15 & 1.15 & 1.06 & 1.09 \\
\hline CAGR 2013/2010 & -0.96 & 1.02 & 1.01 & 1.02 & 1.00 & -1.53 & 1.18 & 1.18 & 1.07 & 1.14 \\
\hline CAGR 2012/2010 & - & 1.03 & 1.01 & 1.04 & 1.02 & - & 1.22 & 1.22 & 1.11 & 1.17 \\
\hline \multirow[t]{2}{*}{ GR 2011/2010 } & 0.18 & 1.03 & 1.02 & 1.03 & 1.00 & 1.18 & 1.24 & 1.25 & 1.08 & 1.25 \\
\hline & $\mathrm{P} / \mathrm{E}$ & $\mathrm{P} / \mathrm{S}$ & $\mathrm{S} / \mathrm{C}$ & $\mathrm{C} / \mathrm{M}$ & $\mathrm{M} / \mathrm{E}$ & $\mathrm{P} / \mathrm{E}$ & $\mathrm{P} / \mathrm{S}$ & $\mathrm{S} / \mathrm{C}$ & $\mathrm{C} / \mathrm{M}$ & $\mathrm{M} / \mathrm{E}$ \\
\hline 2014 & 0.03 & $0 \%$ & 1.19 & 6.28 & 23.55 & 6.56 & $3 \%$ & 1.24 & 6.01 & 27.46 \\
\hline 2013 & 1.45 & $1 \%$ & 1.20 & 6.18 & 23.75 & 1.64 & $1 \%$ & 1.23 & 5.85 & 25.50 \\
\hline 2012 & 1.30 & $1 \%$ & 1.19 & 6.11 & 23.48 & 2.70 & $2 \%$ & 1.23 & 5.28 & 27.53 \\
\hline 2011 & -0.29 & $0 \%$ & 1.17 & 6.40 & 23.08 & -0.63 & $0 \%$ & 1.23 & 5.00 & 26.44 \\
\hline 2010 & -1.63 & $-1 \%$ & 1.16 & 6.47 & 22.42 & -0.67 & $0 \%$ & 1.24 & 4.34 & 30.56 \\
\hline $2014 / 2013$ & 0.02 & 0.02 & 0.99 & 1.02 & 0.99 & 3.99 & 3.57 & 1.01 & 1.03 & 1.08 \\
\hline $2013 / 2012$ & 1.11 & 1.08 & 1.01 & 1.01 & 1.01 & 0.61 & 0.60 & 0.99 & 1.11 & 0.93 \\
\hline $2012 / 2011$ & -4.44 & -4.50 & 1.02 & 0.95 & 1.02 & -4.30 & -3.89 & 1.00 & 1.06 & 1.04 \\
\hline $2011 / 2010$ & 0.18 & 0.17 & 1.01 & 0.99 & 1.03 & 0.94 & 0.94 & 1.00 & 1.15 & 0.87 \\
\hline CAGR 2014/2010 & - & - & 1.01 & 0.99 & 1.01 & - & - & 1.00 & 1.09 & 0.97 \\
\hline CAGR 2013/2010 & -0.96 & -0.95 & 1.01 & 0.99 & 1.02 & -1.35 & $-1 / 30$ & 1.00 & 1.11 & 0.94 \\
\hline CAGR 2012/2010 & - & - & 1.01 & 0.97 & 1.02 & - & - & 1.00 & 1.10 & 0.95 \\
\hline GR 2011/2010 & 0.18 & 0.17 & 1.01 & 0.99 & 1.03 & 0.94 & 0.94 & 1.00 & 1.15 & 0.87 \\
\hline \multirow[t]{2}{*}{$\Delta \mathrm{P} / \mathrm{E}$} & $\Delta \mathrm{P} / \mathrm{E}$ & $(\mathrm{P} / \mathrm{S})$ & $(\mathrm{S} / \mathrm{C})$ & $(\mathrm{C} / \mathrm{M})$ & $(\mathrm{M} / \mathrm{E})$ & $\Delta \mathrm{P} / \mathrm{E}$ & $(\mathrm{P} / \mathrm{S})$ & $(\mathrm{S} / \mathrm{C})$ & $(\mathrm{C} / \mathrm{M})$ & $(\mathrm{M} / \mathrm{E})$ \\
\hline & & 0.03 & 1.44 & 1.46 & 1.44 & & 6.56 & 1.84 & 1.82 & 1.77 \\
\hline \multirow[t]{2}{*}{$2014 / 2013$} & -1.42 & -1.42 & -0.01 & 0.02 & -0.01 & 4.92 & 4.72 & 0.02 & 0.05 & 0.13 \\
\hline & $100 \%$ & $100 \%$ & $1 \%$ & $-2 \%$ & $1 \%$ & $100 \%$ & $96 \%$ & $0 \%$ & $1 \%$ & $3 \%$ \\
\hline \multirow{3}{*}{$2013 / 2012$} & & 1.45 & 1.34 & 1.33 & 1.31 & & 1.64 & 2.75 & 2.77 & 2.50 \\
\hline & 0.15 & 0.11 & 0.01 & 0.02 & 0.02 & -1.05 & -1.10 & -0.02 & 0.27 & -0.20 \\
\hline & $100 \%$ & $73 \%$ & $6 \%$ & $11 \%$ & $10 \%$ & $100 \%$ & $105 \%$ & $2 \%$ & $-25 \%$ & $19 \%$ \\
\hline \multirow{3}{*}{$2012 / 2011$} & & 1.30 & -0.29 & -0.28 & -0.29 & & 2.70 & -0.69 & -0.69 & -0.65 \\
\hline & 1.59 & 1.59 & -0.01 & 0.01 & 0.00 & 3.33 & 3.39 & 0.00 & -0.04 & -0.03 \\
\hline & $100 \%$ & $100 \%$ & $0 \%$ & $1 \%$ & $0 \%$ & $100 \%$ & $102 \%$ & $0 \%$ & $-1 \%$ & $-1 \%$ \\
\hline \multirow{3}{*}{$2011 / 2010$} & & -0.29 & -1.68 & -1.67 & -1.69 & & -0.63 & -0.59 & -0.59 & -0.50 \\
\hline & 1.34 & 1.39 & -0.01 & 0.02 & -0.05 & 0.04 & 0.04 & 0.00 & -0.09 & 0.09 \\
\hline & $100 \%$ & $103 \%$ & $-1 \%$ & $1 \%$ & $-4 \%$ & $100 \%$ & $91 \%$ & $7 \%$ & $-221 \%$ & $223 \%$ \\
\hline
\end{tabular}

Source: compiled by the authors, annual reports 2010-2014.

As it can be seen, during 2010-2012 Selver' share of materials and consumables to total sales was fluctuating around $76.2 \%-77.0 \%$. But in 2013 , there was a rapid growth of materials and consumables share up to $79.1 \%$, what caused profit margin decline. Could be suggested, in its turn, profit margin decline occurred due to strong competition environment on the market and 
consequently, Selver decreased its sales prices or became conducted more aggressive discount policy. In 2013, the decline in profit per employee was slightly balanced by an increase from 16.15 to 19.26 thousand euros per employee in machinery and equipment per employee $(\mathrm{M} / \mathrm{E})$ component due to expansion and opening five new stores in 2013, where additional machinery and equipment were needed.

As with Selver, Rimi's changes in profit per employee can be mainly explained by profit margin factor (Table 3). In 2011-2013, Rimi was able to increase its profit per employee gradually from -1.63 to 1.45 thousand euros per th/employee due to gradual increase in net margin. In 2014, Rimi's profit per employee dropped from 1.45 in 2013 to 0.03 thousand euros per employee due to a decrease in the profit margin from $1 \%$ to $0 \%$. This was mainly caused by the same factors, as in case with Selver (by growth in materials and consumables). It can be seen from income statement that compared to 2013 sales in 2014 increased by $0.6 \%$, but materials and consumables increased by $1.62 \%$, what is indicating about expansion activities and it were required additional materials, consumables and goods for the opening of the new stores.

Like Selver and Rimi, Prisma's changes in profit per employee were mainly driven by changes in profit margin. Prisma had the highest profit per employee and its increase in 2014 was driven by a favourable growth in profit margin (P/S) from $0.9 \%$ in 2013 to $3.2 \%$ in 2014. This was mainly driven by two factors. Firstly, sales increased by $6.5 \%$ in 2014, compared to 2013, while materials and consumables increased only by $5.5 \%$, what is favourable. At the same time, it can be seen that materials and consumables share amounted $80.8 \%$ to total sales in 2014 , while in 2013 it was $81.6 \%$.

It can be concluded that the biggest impact on changes in profit per employee in 2010-2014 among all investigated companies was in the profit margin $(\mathrm{P} / \mathrm{S})$ component. As the net sales to COGS indicator was relatively stable, the changes in profit margin can mainly be explained by other elements that impact operating profit (e.g. how manpower and other operating expenses are managed).

\section{Ranking of supermarket chains based on overall performance efficiency indicator (OPEI)}

As Selver had the highest profit per employee for most of the years, the authors decided to take Selver as a base company for OPEI comparison with other supermarket chains and the calculated comparison matrices (i.e. Selver efficiency matrix components were divided by other supermarkets' matrix components of the same year). According to formula 2 , the $\Sigma$ I coefficient was calculated as a sum of all the components of the comparison matrix.

According to OPEI calculated by arithmetic mean (Table 4), the following findings can be revealed:

- Selver's performance efficiency was higher in comparison to Maxima, Rimi and Prisma during 2010-2013.

- In 2014, Prisma had the highest performance efficiency (Selver had 17\% lower performance efficiency compared to Prisma). 
Table 4. OPEI of Selver by arithmetic and geometric mean in comparison to other supermarket chains 2010-2014 (\%)

\begin{tabular}{|c|c|c|c|c|}
\hline & Year & Maxima & Rimi & Prisma \\
\hline \multirow{5}{*}{ 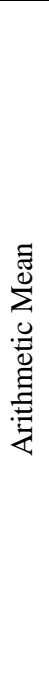 } & 2014 & $\mathbf{8 1} \%=1.81=\frac{2 \times 18.12}{5^{2}-5}$ & $\mathbf{6 1 1 3} \%=62.13=\frac{2 \times 621.34}{5^{2}-5}$ & $-\mathbf{1 7} \%=0.83=\frac{2 \times 8.33}{5^{2}-5}$ \\
\hline & 2013 & $\mathbf{6 7} \%=1.67=\frac{2 \times 16.76}{5^{2}-5}$ & $\mathbf{6 1} \%=1.61=\frac{2 \times 16.14}{5^{2}-5}$ & $\mathbf{5 2} \%=1.52=\frac{2 \times 15.19}{5^{2}-5}$ \\
\hline & 2012 & $165 \%=2.65=\frac{2 \times 26.52}{5^{2}-5}$ & $193 \%=2.93=\frac{2 \times 29.36}{5^{2}-5}$ & $\mathbf{8 2} \%=1.82=\frac{2 \times 18.21}{5^{2}-5}$ \\
\hline & 2011 & $-0.01=\frac{2 \times(-0,13)}{5^{2}-5}$ & $-12.27=\frac{2 \times(-122.72)}{5^{2}-5}$ & $-5.35=\frac{2 \times(-53,59)}{5^{2}-5}$ \\
\hline & 2010 & $\mathbf{4 0} \%=1.40=\frac{2 \times 14.09}{5^{2}-5}$ & $-1.10=\frac{2 \times(-11.01)}{5^{2}-5}$ & $-3.79=\frac{2 \times(-37.94)}{5^{2}-5}$ \\
\hline \multicolumn{2}{|c|}{ Geometric Mean } & $\begin{aligned} \sqrt[3]{1.81 \times 1.67 \times 2.65} & =2.00 \\
& =\mathbf{1 0 0} \%\end{aligned}$ & $\begin{array}{r}\sqrt[3]{62.13 \times 1.61 \times 2.93}=6.65 \\
=565 \%\end{array}$ & $\begin{aligned} \sqrt[3]{0.83 \times 1.52 \times 1.82} & \\
& =1.32 \\
& =\mathbf{3 2} \%\end{aligned}$ \\
\hline
\end{tabular}

Source: compiled by the authors

According to geometric mean calculations, only period 2012-2014 can be comparable among investigated supermarket chains, since in 2010-2011(Rimi, Prisma) and in 2011 (Maxima) $\Sigma$ I coefficient was negative. Therefore, root extraction from the negative value is mathematically impossible and the 2010-2011 period is unrepresentative.

Thus, according to geometric mean calculations in observing the three-year period (20122014), Selver was 565\% more efficient than Rimi, 100\% more efficient than Maxima and 32\% more efficient than Prisma.

\section{Conclusions}

The purpose of this study was to analyse the formation of profit per employee by using matrix analysis and to rank supermarket chains by using an overall performance efficiency indicator.

In general, it was found that profit per employee fell in regard to Maxima and Selver during the 2010-2014 period. In the case of Rimi, it was volatile and increased in 2013, but it decreased in 2014. In Prisma only, this component had positive growth during the 2010-2014 period. According to component analysis, the profit margin mainly impacted changes in profit per employee for all the companies investigated.

According to the OPEI, Selver had the highest performance efficiency, aside from 2014 when Prisma was the most efficient and had the highest increase in profit per employee.

\section{Literature}

Alver, J. (2015). On some new trends in financial statement analysis: the case of Estonia. Unpublished paper. 
Alver, J. (1989). О некоторых теоретических и практических вопросах применения методики матричного анализа эффективности хозяйственной деятельности. Труды Таллинского политехнического института № 689, с. 65-77.

Alver, J., Järve, V. (1987). Cooperatives coherent analysis of the performance. Soviet Estonia Kooperaator, 2 (107), pp. 25-26. (in Estonian)

Global Shopping Center Development Research. Americas, Europe, Asia. (2014). Cushman \& Wakefield Research Publication.

Available on-line at:

http://www.cushmanwakefield.com/ /media/global-reports/Global-Shopping-Centers-

Report_May2014-Update.pdf (11.02.2015)

DTZ. (2013). European Retail Guide. Shopping Centers.

Available on-line at:

http://www.dtz.dk/files/other/Markedsrapport/dtz_european_retail_guide_-

_shopping_centres_march_2013.pdf (11.02.2015)

European Commission. (2015). Minimum wages per month.

Available on-line at:

http://ec.europa.eu/eurostat/statistics-

explained/index.php/File:Minimum_wages,_July_2015_(\%C2\%B9)_(EUR_per_month)_YB1

6.png (11.02.2015)

Eurostat. (2015). Comparative price levels of consumer goods and services.

Available on-line at: http://ec.europa.eu/eurostat/statistics-

explained/index.php/Comparative_price_levels_of_consumer_goods_and_services

(11.02.2015)

Mereste, U. (1965). Majandusliku analüüsi teooria aktuaalseid üldprobleeme. TRÜ Toimetised, 169. Tartu: TRÜ.

Mereste, U. (1987) Theory of economic analysis. Tallinn: Valgus.

Mereste, U. (1984). System integrated analysis and efficiency. Tallinn: Valgus.

Root, A. (1987). Economic efficiency of production and its matrix modeling (on example of industry of the Estonian SSR), Abstract of the PhD thesis. Tallinn. (in Russian)

Siimann, P., Alver, J. (2015). On Using an efficiency matrix in analysing profit per employee (on the basis of the Estonian SME Sector). Zeszyty Teoretyczne Rachunkowosci, no. 84 (140), pp. 195-215.

Statistics Estonia. (2016). Retail sales by economic activities (2001-2015).

Available on-line at: http://pub.stat.ee/px-web.2001/dialog/searchpx2.asp (04.09.2016)

Vensel V. (2001), Panga analüüs ja finantsjuhtimine 1. Teine trükk, TTÜ Kirjastus, Tallinn.

Luur, H. (1982). Проблемы эффективности оперативного управления в условиях функционирования ОАСУ. Автореферат диссертации на соискание ученой степени кандидата экономических наук. Ленинград: Ленинградский государственный университет.

Root, A. (1983). Экономическая эффективность производства и её матричное моделирование (на примере легкой промышленности Эстонской ССР). Автореферат диссертации на соискание ученой степени кандидата экономических наук. Таллин: Институт экономики Академии наук Эстонской ССР. 
Sarap, M. (1989). Формирование и функционирование системы экономического анализа отрасли промышленности (На примере министерства местной промышленности Эстонской (СР). Автореферат диссертации на соискание ученой степени кандидата экономических наук. Вильнюс.

Volt, R. (1989). Разработка модели оценки результатов хозяйствования предприятия (объединения) и её применение в управлении. Автореферат диссертации на соискание ученой степени кандидата экономических наук. Таллин: Институт экономики Академии наук Эстонской ССР. 